\title{
Relationship between intellectual intelligence, Figural Creativity, and Innovation
}

Billy Hendrik ${ }^{\mathrm{a}}$, Nazlena Mohamad Ali ${ }^{\mathrm{b}}$, Riza Sulaiman ${ }^{\mathrm{c}}$, Mardhiah Masril ${ }^{\mathrm{d}}$, and Harry Theozard Fikrie

${ }^{a}$ Institute of Visual Informatics, Universiti Kebangsaan Malaysia, Malaysia; ${ }^{b}$ Institute of Visual Informatics, Universiti Kebangsaan Malaysia, Malaysia; ${ }^{C}$ Institute of Visual Informatics, Universiti Kebangsaan Malaysia, Malaysia; ${ }^{d}$ Faculty of Computer Science,

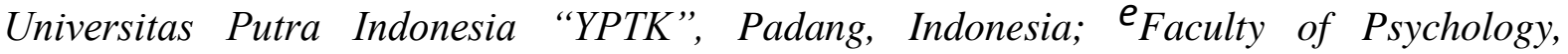
Universitas Putra Indonesia "YPTK”, Padang, Indonesia

*Corresponding author:

Billy Hendrik

Universitas Putra Indonesia "YPTK"

JL. Raya Lubuk Begalung

Padang, West Sumatera, INDONESIA

Telp: +6271 $776666 / 775246 / 73000$

Email address: billy_hendrik@upiyptk.ac.id 


\title{
Relationship between intellectual intelligence, Figural Creativity, and Innovation
}

\begin{abstract}
To compete in the industrial revolution 4.0 era, a country must have qualified human resources. While the intelligence quotient (IQ) has been commonly used as a benchmark for the quality of human resources, according to Peter Drucker (2005), the quality of human resources in a country cannot only be measured by IQ alone as the key to a country's success lies in innovation, which is the result of creativity. This study used quantitative analysis to examine the relationship between intellectual intelligence and creativity (fluency, flexibility, elaboration, and originality) in elementary school students. A random sampling technique was employed to select 80 study participants $(\mathrm{N}=80)$ aged from 10 to 11 years old from four different sub-districts. Colored progressive matrices (CPMs) and a figural creativity test (TKF) were then employed to determine the students' intellectual and creativity levels, after which Statistical Product and Service Solutions was used to analyze the test results and identify the relationship between intellectual intelligence and creativity. The test results corroborated the hypothesis that intellectual ability is related to the ability to think creatively as was indicated by the obtained significance value of $0.04<0.05$. It was found that elaboration and originality were connected with a high average intellectual intelligence, which in this study was only $6.25 \%$ of the sample. Therefore, it is recommended that schools develop teaching materials that stimulate elaboration and originality in students to ensure the development of a high quality generation.
\end{abstract}

Keywords: Creativity, Intelligence, Fluency, Flexibility, Elaboration, Originality.

\section{Introduction}

To compete in the industrial revolution 4.0 era, a country must have qualified human resources. While the intelligence quotient (IQ) has been commonly used as a benchmark for the quality of human resources, according to Peter Drucker (2005), the quality of human resources in a country cannot only be measured by IQ alone as the key to a country's success lies in innovation, which is the result of creativity and creativity is the result of people creative intelligence combined with analytical and practical intelligence (Okpara, 2007). Fadaee (2014) defined the relationship between innovation and creativity, where innovation converts a creative invention or idea into marketable products or service (Fadaee, 2014); that is, the innovative process is the materialization of the creative idea (Faria, 2008) Innovation is also when a product or process is updated or refined to produce something new (Okpara , 2007). Therefore, an innovation is the ability to mobilize creative ideas, and creativity brings about innovation. Innovation and creativity in the workplace have become increasingly important determinants of organizational performance, success, and longer-term survival (West, 2002; Zhou, 2003; Anderson \& Potocnik, 2014). The relationship between creativity and product innovation is understanding the creative process so as to be able to generate new ideas that can lead to innovative products (da Silva Marinho et al., 2016) 
Several factors are associated with creativity, one of which is intelligence. Several studies have been conducted to analyze the relationship between intelligence and creativity. Shi et al. (2017) found that there was a weak relationship between creativity and intelligence for IQs above 120 but not for IQs below 120, Casakin \& Kreitler (2014) examined how intelligence and creativity were connected, and Plucker \& Esping, (2015) found that children who have a low IQ with high creativity were able to match the academic achievements of children with low creativity and a high IQ (Palaniappan, 2005).

The few studies that have been conducted to investigate the relationship between intellectual intelligence and creativity have used divergent thinking test batteries such as the Torrance Tests of Creative Thinking (TTCT) and the Wallach-Kogan Creativity Tests (WKCT). However, in this study, the creativity of the students was measured using the figural creativity test (TKF) to determine the relationship between intellectual intelligence and fluency, flexibility, elaboration, and originality.

Because creative children can improve the future quality of human resources, the findings in this research could lead to a better understanding of the importance of creativity in the national education system.

\section{Method}

\section{A. Participant}

Field observations were first conducted at a Private Elementary School in Padang. Padang was chosen as it is a largest and most popular educational city on Sumatra Island in Indonesia. The schools and students were then selected using random sampling techniques, with to students from each of four schools being chosen; therefore, the total research sample was 80 students aged 10 to 11 years old. This age group was selected because the development of creativity at this age has been found to be from 50\%-70\% (Rushton, Skuy, \& Fridjhon, 2003; Thang, Sluis-Thiescheffer, Bekker, Eggen, Vermeeren, de Ridder, 2008; Mangiwa, 2014) as the children are in a concrete operational stage; that is, they have the ability to think rationally, are imaginative, and have the ability to explore more objects or situations to solve problems (Sarayati, n.d.). Piaget's cognitive development theory states that in the concrete operational stage, children are beginning to build their thinking skills based on logic (Dalamu, 2017; Ghazi, 2015; Wood, Smith, \& Grossniklaus, 2001).

\section{B. Instrument}

\section{Colored Progressive Matrices (CPM)}

The CPM can be used on children aged 5-11 years, children who are experiencing mental barriers, children with intellectual disabilities, and the elderly over 60 years who have low or medium education.

Raven (2000) claimed that the CPM tests were able to reveal aspects such as:

- thinking logically;

- spatial observation skills; 
- the ability to find and understand the relationship between whole and parts including analysis and integration capabilities; and

- analogical thinking skills.

CPM tests can be conducted either individually or classically, depending on the needs, with the results being a percentile and an intelligence grade.

A student's intellectual test score is classified into several levels, as shown in Table 1.

Table I. IQ Based on the Stanford Binet Standard

\begin{tabular}{|l|l|l|}
\hline Grade SPM & \multicolumn{1}{|c|}{$\begin{array}{c}\text { Range IQ based on the } \\
\text { Standford Binet standard }\end{array}$} & \multicolumn{1}{|c|}{ Klasifikasi } \\
\hline Grade I & $120-139$ & Superior \\
\hline Grade II & $110-119$ & High Average \\
\hline Grade III & $90-109$ & Average \\
\hline Grade IV & $80-89$ & Low Average \\
\hline Grade V & $68-79$ & $\begin{array}{l}\text { Borderline Intellectual } \\
\text { disability }\end{array}$ \\
\hline
\end{tabular}

\section{Figural Creativity Test (TKF)}

The students' figural creativity was measured using the figural creativity test (TKF), which is part of the Torrance Test of Creativity Thinking (TTCT) and an adaptation of Torrance's Circle Test, and was standardized in 1988 (Munandar et. al.1988). The figural creativity test (TKF), which was first used in Indonesia by Utami Munandar in 1977, measures the originality, fluency, flexibility, and elaboration associated with the ability to creatively form new combinations of given elements. Some elements that determine the figural creativity of students (Casakin \& Kreitler, 2014; Cassia, Pontificia, \& Paulo, 2015; Visentricia, Sudarisman, \& Ariyanto, 2015; Marzieh \& Arefi, 2016).

Originality is the ability to produce an idea that is different from most people in the group. As answer is considered original if the response is given by less than $10 \%$ of the population, with criteria such as if students are in a group of 5\% given a score $=1$. Fluency measures the ability to think and come up with a variety of ideas quickly and precisely, with the number of responses determining the score. Flexibility measures the ability to provide ideas from different perspectives, with the score being given based on the number of categories, and elaboration measures the ability to develop, detail and complete an idea or ideas.

\section{Procedure}

After receiving approval from the schools, the CPM was conducted over 25 minutes with the 80 selected students. The CPM has 36 questions grouped into three series; A, Ab, and B; ranging from easy to difficult. Each question consists of a large image that has a missing piece, below which are six choices. The students choose the best image to complete the larger picture. The intelligence tests were administered before the figural creativity tests.

The total figural creativity test score is calculated from the number of characteristics that appear in the student's answers. There are three steps to the figural creativity test: first, the students create an image of a predetermined pattern in a circle; then, the students complete an 
image based on the pattern provided; and finally, the students create an image within 10 minutes using a circular pattern that varies as much as possible from the image given (Garaigordobil, 2006).

The originality score involves tabulating the answers of 500 subjects aged $10-18$ years. The answers given by $10 \%$ or more of the subjects are given a score of 0 , answers given by $5-9 \%$ of the subjects are given a score of 1 , answers given by $2-4 \%$ of subjects are given a score of 2 , and answers given by less than $2 \%$ of the subjects and answers not included in the list of originalities are given a score of 3. Merging two circles given 2 bonus points. Merging given circle 5. Merging 3-5 6-10 11-15 circles given Merging given 10. 15. 20. Join 15 circles given merge all the circles are given 25 . The elaboration score was measured based on the number of ideas generated in addition to the minimum basic idea, with each addition being given a score of 1 . Then, the scores for all four elements were calculated as well as a total score, with the total score being the creativity measure.

\section{Result}

The intellectual levels of the student sample were measured using the CPM, and based on the test results, the students were divided into five subgroups: grade I, grade II, grade III, grade IV and grade V. Therefore, the results from the 80 students were as follows; 24 students were grade I, 32 students were grade II, 21 students were grade III, 2 students were grade IV, and 1 was grade $\mathrm{V}$ (Fig.1).

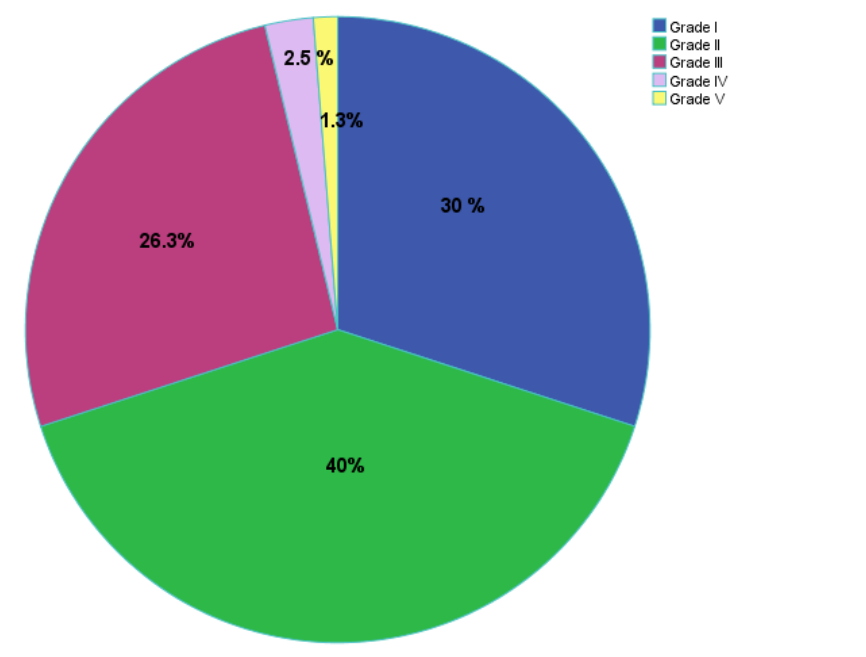

Fig.1. Intellectual level of student sample

To determine whether there was a relationship between intelligence and creativity the correlations were determined using Pearson's correlation. 
Table II. Correlation between Measures of Intelligence and Figural Creativity

\begin{tabular}{|c|l|l|}
\hline & $\begin{array}{l}\text { TKF } \\
\text { Score }\end{array}$ & $\begin{array}{l}\text { CPM } \\
\text { Score }\end{array}$ \\
\hline Pearson & 1 & $.225^{*}$ \\
Correlation & & \\
TKF Score Sig. (2-tailed) & & .044 \\
N & 80 & 80 \\
\hline
\end{tabular}

*. Correlation is significant at the 0.05 level (2-tailed).

As can be seen from table 2, the correlations between intelligence and figural creativity were significant (significant value 0.044) and positive (0.225). After the beginning stage was completed, the second stage determined whether there was a relationship between intelligence and the fluency, flexibility, originality, and elaboration elements.

Table III. Fluency Ability and Intelligence Level

\begin{tabular}{|c|l|l|l|l|l|l|}
\hline \multirow{2}{*}{ Fluency } & \multicolumn{5}{|c|}{ CPM Level } \\
\cline { 2 - 6 } & $\begin{array}{l}\text { Grade } \\
\text { I }\end{array}$ & $\begin{array}{l}\text { Grade } \\
\text { II }\end{array}$ & $\begin{array}{l}\text { Grade } \\
\text { III }\end{array}$ & $\begin{array}{l}\text { Grade } \\
\text { IV }\end{array}$ & $\begin{array}{l}\text { Grade } \\
\text { V }\end{array}$ & \\
\hline 7 & 2 & 0 & 3 & 0 & 0 & 5 \\
8 & 5 & 8 & 7 & 1 & 1 & 22 \\
9 & 3 & 4 & 2 & 0 & 0 & 9 \\
10 & 5 & 6 & 3 & 1 & 0 & 15 \\
11 & 3 & 7 & 4 & 0 & 0 & 14 \\
12 & 3 & 2 & 1 & 0 & 0 & 6 \\
13 & 2 & 1 & 0 & 0 & 0 & 3 \\
14 & 1 & 3 & 0 & 0 & 0 & 4 \\
15 & 0 & 1 & 1 & 0 & 0 & 2 \\
Total & 24 & 32 & 21 & 2 & 1 & 80 \\
\hline
\end{tabular}

The fluency abilities were in the range of $0-20(\min =7, \max =15$, mean $=9.91, \mathrm{SD}=$ 2.014). As can be seen in table 3, the 2 students with the highest values had grade II and grade III intelligence levels.

Table IV. Flexibility and Intelligence Level

\begin{tabular}{|c|l|l|l|l|l|l|}
\hline \multirow{2}{*}{ Flexibility } & \multicolumn{4}{l|}{ CPM Level } & Total \\
\cline { 2 - 6 } & $\begin{array}{c}\text { Grade } \\
\text { I }\end{array}$ & $\begin{array}{l}\text { Grade } \\
\text { II }\end{array}$ & $\begin{array}{l}\text { Grade } \\
\text { III }\end{array}$ & $\begin{array}{l}\text { Grade } \\
\text { IV }\end{array}$ & $\begin{array}{l}\text { Grade } \\
\text { V }\end{array}$ & \\
\hline 6 & 0 & 0 & 1 & 0 & 0 & 1 \\
7 & 1 & 2 & 0 & 0 & 0 & 3 \\
8 & 5 & 3 & 4 & 1 & 0 & 13 \\
\hline
\end{tabular}




\begin{tabular}{|c|l|l|l|l|l|l|}
\hline 9 & 2 & 3 & 5 & 0 & 1 & 11 \\
10 & 2 & 8 & 5 & 0 & 0 & 15 \\
11 & 4 & 5 & 1 & 1 & 0 & 11 \\
12 & 5 & 7 & 3 & 0 & 0 & 15 \\
13 & 2 & 0 & 0 & 0 & 0 & 2 \\
14 & 1 & 3 & 0 & 0 & 0 & 4 \\
15 & 1 & 1 & 1 & 0 & 0 & 3 \\
16 & 1 & 0 & 1 & 0 & 0 & 2 \\
Total & 24 & 32 & 21 & 2 & 1 & 80 \\
\hline
\end{tabular}

The flexibility abilities were in a $0-20$ range $(\min =6, \max =16$, mean $=10.50, \mathrm{SD}=2.210)$. As can be seen in table 4, there were 2 students with the highest values, who had grade I and grade III intelligence levels.

Table V. Originality and Intelligence Level

\begin{tabular}{|c|l|l|l|l|l|l|}
\hline \multirow{2}{*}{ Originality } & \multicolumn{5}{|c|}{ CPM Level } & Total \\
\cline { 2 - 5 } & $\begin{array}{l}\text { Grade } \\
\text { I }\end{array}$ & $\begin{array}{l}\text { Grade } \\
\text { II }\end{array}$ & $\begin{array}{l}\text { Grade } \\
\text { III }\end{array}$ & $\begin{array}{l}\text { Grade } \\
\text { IV }\end{array}$ & $\begin{array}{l}\text { Grade } \\
\text { V }\end{array}$ & \\
\hline 7 & 2 & 1 & 2 & 0 & 0 & 5 \\
8 & 1 & 3 & 5 & 0 & 1 & 10 \\
9 & 3 & 2 & 2 & 0 & 0 & 7 \\
10 & 2 & 6 & 1 & 1 & 0 & 10 \\
11 & 3 & 7 & 2 & 1 & 0 & 13 \\
12 & 3 & 6 & 4 & 0 & 0 & 13 \\
13 & 6 & 1 & 3 & 0 & 0 & 10 \\
14 & 1 & 2 & 2 & 0 & 0 & 5 \\
15 & 1 & 0 & 0 & 0 & 0 & 1 \\
17 & 0 & 3 & 0 & 0 & 0 & 3 \\
18 & 1 & 0 & 0 & 0 & 0 & 1 \\
19 & 1 & 0 & 0 & 0 & 0 & 1 \\
20 & 0 & 1 & 0 & 0 & 0 & 1 \\
Total & 24 & 32 & 21 & 2 & 1 & 80 \\
\hline
\end{tabular}

The originality abilities were in $0-20$ range $(\min =7, \max =20$, mean $=11.25, \mathrm{SD}=2.799)$. As can be seen in table 5, the originality value $>17$ for the grade I and grade II intellectually intelligent students.

Table VI. Elaboration and Intellectual Intelligence

\begin{tabular}{|c|l|l|l|l|l|l|}
\hline \multirow{2}{*}{ Elaboration } & \multicolumn{5}{|c|}{ CPM Level } \\
\cline { 2 - 6 } & $\begin{array}{c}\text { Grade } \\
\text { I }\end{array}$ & $\begin{array}{l}\text { Grade } \\
\text { II }\end{array}$ & $\begin{array}{l}\text { Grade } \\
\text { III }\end{array}$ & $\begin{array}{l}\text { Grade } \\
\text { IV }\end{array}$ & $\begin{array}{l}\text { Grade } \\
\text { V }\end{array}$ & \\
\hline 4 & 1 & 2 & 4 & 0 & 1 & 8 \\
5 & 12 & 15 & 10 & 2 & 0 & 39
\end{tabular}




\begin{tabular}{|c|l|l|l|l|l|l|}
6 & 2 & yan7 & 3 & 0 & 0 & 12 \\
7 & 2 & 0 & 1 & 0 & 0 & 3 \\
8 & 2 & 4 & 1 & 0 & 0 & 7 \\
9 & 2 & 1 & 0 & 0 & 0 & 3 \\
10 & 2 & 0 & 1 & 0 & 0 & 3 \\
11 & 0 & 0 & 1 & 0 & 0 & 1 \\
12 & 0 & 1 & 0 & 0 & 0 & 1 \\
13 & 0 & 2 & 0 & 0 & 0 & 2 \\
20 & 1 & 0 & 0 & 0 & 0 & 1 \\
Total & 24 & 32 & 21 & 2 & 1 & 80 \\
\hline
\end{tabular}

The elaboration abilities were in the $0-20$ range $(\min =4, \max =20$, mean $=6.28, \mathrm{SD}=$ 2.580). As can be seen in table 6, the highest elaboration value was achieved by the intellectually intelligent grade I students.

The Pearson's correlation calculation for creativity figural elements (fluency, flexibility, originality, elaboration) with intelligence is shown in table 7.

Table VII. Correlation Among the Total Scores for the Intelligence and Creativity Measures

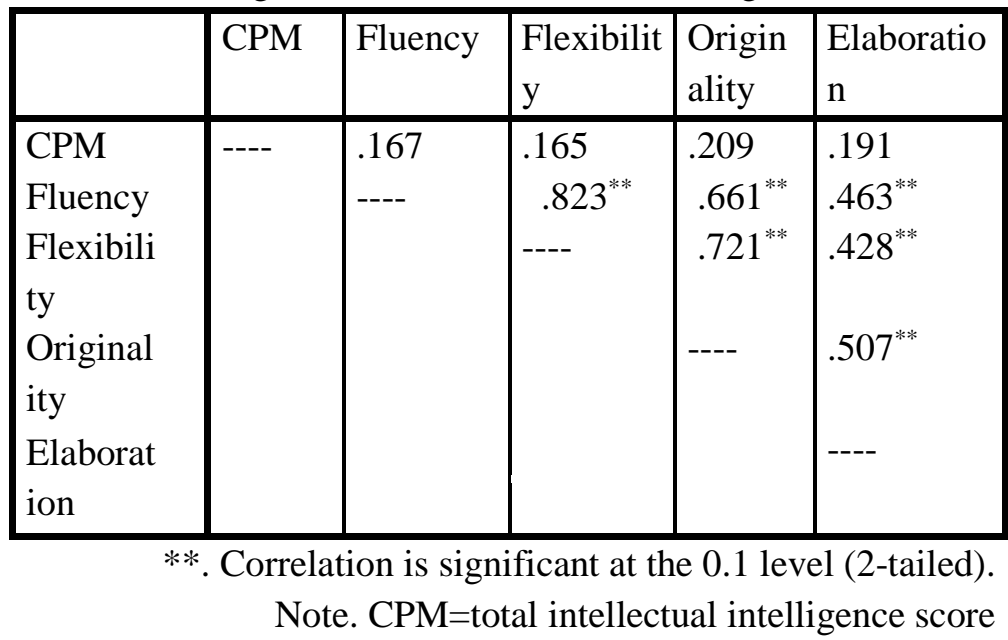

As can be seen in table 7, low correlations were found between the total intellectual intelligence score and originality (.209). However, very low correlations were found between the total intellectual intelligence score and fluency abilities (.167), flexibility abilities (.165), and elaboration abilities (.191).

Only $5 \%$ of the students in the sample had higher originality values, of which $75 \%$ of had an intellectual intelligence of grade I and $25 \%$ had an intellectual intelligence of grade II. While innovation and elaboration are important to originality, only 1 student (1.25\% of the total sample) scored the highest value of grade I for intelligence elaboration ability, and only $6.25 \%$ of students were found to have high originality and elaboration abilities, all of whom had high average intellectual intelligence. 


\section{Discussion}

This study found a moderate correlation between intellectual intelligence and creativity. The first analysis found a relationship between intellectual intelligence and figural creativity in students with a positive direction, i.e., a student's intellectual intelligence will be directly proportional to their figural creativity. With the value of the correlation coefficient is the correlation value is low.

These results were consistent with the results in Nakano, Weschler, Campos, and Milian (2015) in which the correlation for figural creativity was found to be lower than correlation between intelligence and verbal creativity. Likewise, Nakano and Brito (2013) found in a reasoning subtest that there was also a low correlation between intelligence and figural creativity. Benedek also sought to explain the shared variance between intelligence and creativity (Benedek, Jauk, Sommer, Arendasy, \& Neubauer, 2014). These findings provide direct support for the executive involvement in creative thought and shed further light on the functional relationships between intelligence and creativity.

The second analysis found a correlation between the total intellectual intelligence score and figural creativity elements (fluency, flexibility, originality, and elaboration). A low correlation was found between the intellectual intelligence score and originality, which was consistent with past research in which it was found that the latent originality and fluency variables significantly predicted intelligence (Silvia, 2008).

The results of this study found that intellectual intelligence had a relationship with creativity primarily through the originality factor. Of the total sample of 80 students $(\mathrm{N}=80), 25$ students had an intellectual intelligence level of grade I, only 3 students had higher value for the originality factor, and only 1 student had the highest values for the elaboration factor. Thirty-five students were found to have an intellectual intelligence level of grade II and only 1 student had a higher originality factor. Elaboration and originality were quite high in the students with high average intellectual intelligence; however, these students made up only $6.25 \%$ of the sample. Originality was found to be central to the creativity judgments (Runco, \& Acar, 2012).

Originality has been found to be important in generating innovation generating novel ideas (Shively, 2011). Originality has been the prerequisite for world-changing science (Scheffer, Baas, \& Bjordam, 2017) and is the most advanced characteristic of creativity needed for the development of innovative products (Al-Oweidi, 2013). Although the words creativity and originality may suggest complete novelty, creative production essentially builds on a combination of existing elements. Elaboration is the realization or transformation of an idea, which may be very general or simple or very fantastic (Al-oweidi, 2013). Elaboration is the ability to design the details of a product to make it appear perfect (Shively, 2011).

Very few student sample were found to have originality and elaboration abilities indicating that there may be very few future Indonesian human resources capable of generating 
innovations that can compete with other countries in industrial revolution 4.0. Creativity is the active process necessary for innovation (Vygotsky, 1992) Therefore, this study suggests that schools need to develop teaching materials and teaching methods that can stimulate the elaboration and originality abilities of the students.

\section{Conclusion}

- All students who scored the highest in all figural creativity aspects (fluency, flexibility, originality, elaboration) had grade III or higher intellectual intelligence.

- The students who has high average intellectual intelligence had more new ideas, and those who had the highest originality and elaboration had grade I and grade II intellectual intelligence.

- There was a low correlation between intellectual intelligence and the originality figural creativity component, indicating that there needed to be greater creativity stimulation in the education curriculum.

- Few students were found to have high originality or elaboration abilities, which indicated that in the future, there may be few Indonesian human resources who could generate innovations to compete with other countries because creativity is at the heart of innovation.

\section{Acknowledgments}

This research was supported by LLDIKTI from The Ministry of Research and Technology to fund this research through the "Penelitian Strategis Nasional Institusi" program.

\section{References}

Al-Oweidi, A. (2013). Creative Characteristics and Its Relation to Achievement and School Type among Jordanian Students. Creative Education, 4(01), 29-34.

Anderson, N., Potočnik, K., \& Zhou, J. (2014). Innovation and creativity in organizations: A state-of-the-science review, prospective commentary, and guiding framework. Journal of management, 40(5), 1297-1333.

Benedek, M., Jauk, E., Sommer, M., Arendasy, M., \& Neubauer, A. C. (2014). Intelligence, creativity, and cognitive control: The common and differential involvement of executive functions in intelligence and creativity. Intelligence, 46, 73-83.

Casakin, H., \& Kreitler, S. (2006). Evaluating creativity in design problem solving. Wonderground, the.

Dalamu, T. O. (2017). Nigerian Children Specimens as Resonance of Print Media Advertising: What for? Acta Universitatis Danubius, 11(2), 79-111.

da Silva Marinho, E., González, M. O. A., Galvão, M. S., de Araújo, A. C. C., Rosa, M. S. C., \& Pereira, J. R. (2016). Relationship between creativity and product innovation: a literature review. ResearchGate, (August). https://doi.org/10.4322/pmd.2016.007

Drucker, P. (2005). Creative Intelligence. Denmark.

Fadaee, A., \& Abd Alzahrh, H. O. (2014). Explaining the Relationship between Creativity, Innovation and Entrepreneurship. International Journal of Economy, Management and Social Sciences, 3(12), 1-4.

Faria, B. (2008). Gestão da Inovação. Belo Horizonte, 6(2), 104-117.

Garaigordobil, M. (2006). Intervention in creativity with children aged 10 and 11 years: Impact of a play program on verbal and graphic-figural creativity. Creativity Research Journal, 18(3), 329-345.

Ghazi, S. R., \& Ullah, K. (2015). Concrete operational stage of Piaget's cognitive development theory: An implication in learning general science. Gomal University Journal of Research [GUJR], 31(1), 78-89. 
Mangiwa, R., Wungouw, H. I. S., \& Pangemanan, D. H. C. (2014). Kemampuan Intelligence Quotient (Iq) Mahasiswa Fakultas Kedokteran Universitas Sam Ratulangi. Jurnal e-Biomedik, 2(3).

Marzieh, A. \& Jalali, N. (2016, Feb. $\left.27^{\text {th }}-29^{\text {th }}\right)$. Comparation of Creativity Dimensions (Fluency, Flexibility, Elaboration, Originality) between Bilingual Elementary Students (Azari language-Kurdish language) in Urmia City - Iran. Paper presented at The IAFOR International Conference on Language Learning, Dubai, UAE.

Nakano, T. D. C., Wechsler, S. M., Campos, C. R., \& Milian, Q. G. (2015). Intelligence and creativity: Relationships and their implications for positive psychology. Psico-USF, 20(2), 195-206.

Okpara, F. O. (2007). The value of creativity and innovation in entrepreneurship. Journal of Asia entrepreneurship and sustainability, 3(2), 1.

Palaniappan, A. K. (2007). Academic achievement of groups formed based on creativity and intelligence. Linköping Electronic Conference Proceedings, 20(21), 141-151.

Plucker, J. A., \& Esping, A. (2015). Intelligence and creativity: A complex but important relationship. Asia Pacific Education Review, 16(2), 153-159. https://doi.org/10.1007/s12564-015-9374-9.

Raven, J. (2000). The Raven's progressive matrices: change and stability over culture and time. Cognitive psychology, 41(1), 1-48.

Runco, M. A., \& Acar, S. (2012). Divergent thinking as an indicator of creative potential. Creativity Research Journal, 24(1), 66-75. https://doi.org/10.1080/10400419.2012.652929.

Rushton, J. P., Skuy, M., \& Fridjhon, P. (2003). Performance on Raven's advanced progressive matrices by African, East Indian, and White engineering students in South Africa. Intelligence, 31(2), 123-137.

Sarayati, S. (n.d.). Analisis Faktor Perilaku. Universitas Airlangga.

Scheffer, M., Baas, M., \& Bjordam, T. (2017). Teaching originality? Common habits behind creative production in science and arts. Ecology and Society, 22(2), 29.

Shi, B., Wang, L., Yang, J., Zhang, M., \& Xu, L. (2017). Relationship between divergent thinking and intelligence: An empirical study of the threshold hypothesis with Chinese children. Frontiers in psychology, 8, 254.

Shively, C. H. (2011). Grow Creativity! Learning \& Leading with Technology, 38(7), 10-15.

Silvia, P. J. (2008). Creativity and intelligence revisited: A reanalysis of Wallach and Kogan (1965). Creativity Research Journal, 20, 34-39.

Thang, B., Sluis-Thiescheffer, W., Bekker, T., Eggen, B., Vermeeren, A., \& de Ridder, H. (2008). Comparing the creativity of children's design solutions based on expert assessment. Proceedings of the 7th international conference on Interaction design and children, 266-273.

Vinsentricia, A., Sudarisman, S., \& Ariyanto, J. (2015). Efforts to improve students' figural creativity through the use of 5e learning cycle with interrelationship diagram on review of vermes class X-8 SMA Negeri 3 Surakarta Academic Year 2012/2013. Pendidikan Biologi, 7(3).

Vygotsky, L. (1992). Chapter 4 : Innovation and creativity. In Developing the Cambridge learner attributes (Vol. 11, pp. 53-74).

West, M. A. (2002). Sparkling Fountains or Stagnant Ponds : An Integrative Model of Creativity and Innovation Implementation in Work Groups. Applied Psychology: An International Review, 51(3), 355-424.

Wood, K. C., Smith, H., \& Grossniklaus, D. (2001). Piaget's stages of cognitive development. Emerging perspectives on learning, teaching, and technology. Retrieved from http://projects.coe.uga.edu/epltt.

Zhou, J. (2003). When the presence of creative coworkers is related to creativity: Role of role of supervisor close monitoring, developmental feedback, and creative personality. Journal of Applied Psychology, 88(3), 413-422. https://doi.org/10.1037/0021-9010.88.3.413 